\title{
Corporate Governance and the Performance of Seasoned Equity Offering Firms in Nigeria: The Mediating Effect of Agency Costs
}

\author{
Mohammed Aminu Bello, Aminu Kado Kurfi, Bamidele Adeboye Adepoju, Abdu Ja'afaru Bambale \\ Department of Business Administration and Entrepreneurship, Bayero University, Kano, Nigeria
}

Email address:

shariffbelloj@yahoo.com (M. A. Bello), shariffbelloj@gmail.com (M. A. Bello)

\section{To cite this article:}

Mohammed Aminu Bello, Aminu Kado Kurfi, Bamidele Adeboye Adepoju, Abdu Ja'afaru Bambale. Corporate Governance and the Performance of Seasoned Equity Offering Firms in Nigeria: The Mediating Effect of Agency Costs. Journal of Finance and Accounting. Vol. 4, No. 3, 2016, pp. 111-125. doi: 10.11648/j.jfa.20160403.13

Received: April 6, 2016; Accepted: April 18, 2016; Published: May 14, 2016

\begin{abstract}
The objective of this study is to implement Analysis of Moment Structure (AMOS) at the same time analysing the power of corporate governance on Post - Seasoned Equity Offerings (SEO's) performance as well as in determining whether agency costs exist as a mediating variable between them. We conjecture that the mediating function of agency costs reduction is fundamental to the causal relationship between corporate governance and Post-SEO underperformance. Failure to tackle agency costs as a mediating variable may perhaps be one reason for the inconclusive findings in the allied literature. This study intends to focus on an SEO sample, for the reason that it is essential to evaluate how better corporate governance mechanisms can enhance SEO performance by estimating the relationship between different variables. To achieve this, the study will apply the approach and analyse SEOs in Nigeria from 2005-2015.
\end{abstract}

Keywords: Equity, Corporate Governance, Agency Costs, Performance

\section{Introduction}

Every activity following the listing of the company still requires financial support. It is a well known fact that funds could be raised through the issuance of equity securities that is, seasoned equity offerings (SEOs). Consistent with the pecking order model or the discussion of [78] and [85], issuance of equity securities can be regarded as a signal of subsequent underperformance. Earlier studies have indicated that investors who invest in SEOs often exhibit excessive and irrational optimism. This optimism increases investor willingness to purchase stocks at higher prices causing temporary overvaluations [42]. Additionally, managers will use this opportunity for stock issuance provided they are able to establish that the market is ready to pay more for their stocks. In any case, after clarifying the real conditions of the issuing companies, investors ultimately realize the overvalued price and will engage in corrective action which subsequently results in poor long-term stock performance.

The dilution of insider control after issuance is associated with increasing agency costs, as pointed out by [49].
Therefore, agency costs increase as the separation of ownership and control after issuance leads to greater conflict between managers and shareholders [42]. Furthermore, the inability of companies to use accumulated capital appropriately can bring about agency problems which will further damage the firm value, at the same time that of the shareholders wealth.

According to [88]; [56]; [43] governance mechanisms are aimed at eliminating the agency problem between the agent and the principal and to also reduce inefficiencies. Since corporate governance is responsible for safeguarding functions, it has to be effective in controlling agency problems toward improving the performance of firms after SEO.

As established in prior studies, through corporate governance monitoring mechanisms, corporations can mitigate agency problems and reduce the information asymmetry between the corporation and investors. Effective corporate governance practices may also increase the value of issuing firms. Nevertheless, evidence surrounding the impact of governance on issuing firms' performance is mixed 
and inconclusive. Extensive literature has documented the beneficial role of effective governance in improving the performance of SEOs e.g. [8]; [47]\&[95]; [1]; [66]; [86] [24] [43]; [51]; [2]; [93].

Similarly an additional strand of the literature documented the role of effective corporate governance in the performance of firms e.g. [34]; [94]; [8];[46]; [14]; [32]; [31]; [57]; [29]; [92]; [1]; [2]; [82];[66]; [23]; [37]; [27]; [45]; [11]; [47]; [12].

Nevertheless, contrary results as well appear in the literature. [49] Established a negative relationship and concluded that it was an agency problem. [23] Documents deterioration of long-term operating performance and the capital structure of SEO firms deteriorate for up to two years following the announcement.

[21] Could not find any relationship between firm performance and either insider's or institutional ownership for SEOs. [60] Concluded that there is no reliable evidence that corporate governance is related to operating or financial performance. Moreover, other studies support the view that a firm's governance structure is endogenously determined. Factors such as managerial ownership according to [39], board characteristics [38], and ownership concentration [13] are products of the firm's organizational and economic environments.

In addition to examining the direct effects of governance structure on firm performance, the researcher intends to establish an analysis of moment structure (AMOS) setting by means of including the mediating variable of agency costs into the association between corporate governance and subsequent SEO performance. The primary reason is that a great deal of literature has been documented in relation to the benefit of corporate governance on firm performance through the reduction of agency costs. [67] States that, "After the IPO, the evolution of internal corporate governance mechanisms are expected to reduce agency costs by aligning the interests and help to mitigate the negative effects of increasing agency costs on the long-term firm performance." [61], [5], [53], and [15] also make similar statements.

In view of that, one may discern that reducing agency costs is the most significant step towards better corporate governance in order to achieve an enhanced post-SEO performance. Nevertheless, the literature does not seem to tackle this issue by means of empirical investigation. Researcher's investigation identified only a single empirical investigation by [42] on the issue and the research was conducted in the U. S.

The objective of this study is to analyse the power of corporate governance on post-SEO performance as well as to determine whether agency costs exist as a mediating variable between them through the use of AMOS. We conjecture that the mediating function of agency costs reduction is fundamental to the causal relationship between corporate governance and post-SEO underperformance. Failure to tackle agency costs as a mediating variable may perhaps be one reason for the inconclusive findings in the allied literature.
According to [42] mediating effect refers to the mediating mechanism between the independent and dependent variables. According to Baron and Kenny (1986) as cited in [42] three conditions must be fulfilled for a mediating variable in a regression: that there is a significant correlation between the independent and mediating variable; there is a significant correlation between the mediating variable and the dependent variable; and the inclusion of the mediating variable decreases the strength of the direct relationship between the independent and the dependent variables. However, if the addition of a mediating variable does not alter the statistical significant relationship between the independent and dependent variables, the result is a partial mediating effect. Conversely, where the direct effect becomes insignificant, the result is a full mediation effect.

Since AMOS is a Structural Equation Model (SEM), it has the capability of expressing the relationship between independent and dependent variables, although it differs from multivariate analysis of variance and the standard correlation analysis in that it only allows for single relationship variables. Whereas a variable can be a dependent variable (agency costs) of another variable (corporate governance), it is as well the independent variable for another variable (postissue performance). Series of structural equation models can be used in analysing these complex causal relationships (Hair, Anderson, Tatham, and Black, 1998) cited in [42].

To the best of the researcher's knowledge no research evidence exists at the moment as to the relationship between corporate governance and performance of firms after SEO's in Nigeria. However, there are few studies on the impact of corporate governance and firm performance e.g. [55]; [19]; [92]; [45]; [11]. The study therefore, intends to fill this gap in Nigeria and to improve on the earlier study of [42] from the global perspective by examining a combination of both internal and external corporate governance variables as against only external corporate governance variables by [42].

This study intends to focus on an SEO sample, for the reason that it is essential to evaluate how better corporate governance mechanisms can enhance SEO performance by estimating the relationship between different variables. To achieve this, the study will apply the AMOS approach to analyse SEOs in Nigeria from 2005-2015.

Our primary contribution to the literature will be an allinclusive analysis of the relationship between corporate governance and post-SEO performance through the mediating variable of agency costs. We take into account the endogenous nature of the relation between governance and post-SEO performance. Also, with the help of an Analysis of Moment Structure (AMOS) in the structural equation model (SEM) we take into account the relations among corporate governance, performance and agency costs. Instead of considering just the direct relationship between corporate governance and operating performance, we included agency costs as a mediating variable. This research will further contribute to the literature by providing comprehensive proof of whether agency problems results in the underperformance of SEOs; providing a thorough investigation of the 
relationship between corporate governance and the performance of firms after SEOs through taking into account the likely endogeneity between variables, as relationship tests in an AMOS setting offer more dependable results than normal causality models. The study will therefore, expand the research frontiers for corporate governance, SEOs underperformance, and agency theory; and demonstrate what value better corporate governance can add to shareholders wealth in the issuing context.

The next section provides the research framework in a figure and the discussion of the relevant theories that will be used to underpin the study, Section III provides the literature review and the hypotheses of the study. Section IV describes the research method, variables definition, measures and the data sources.

\section{Theoretical Framework/Model of the Study}

\subsection{Empirical Model of the Study}

The figure below shows a path analysis model depicting the relationship between corporate governance variables, Agency costs and Post-SEO Performance. Corporate Governance is the exogenous variable (independent variable) in the model and Agency costs and Post-SEO performance are the endogenous variables that are divided into a mediating variable (Agency costs) and a dependent variable (Post-SEO Performance).

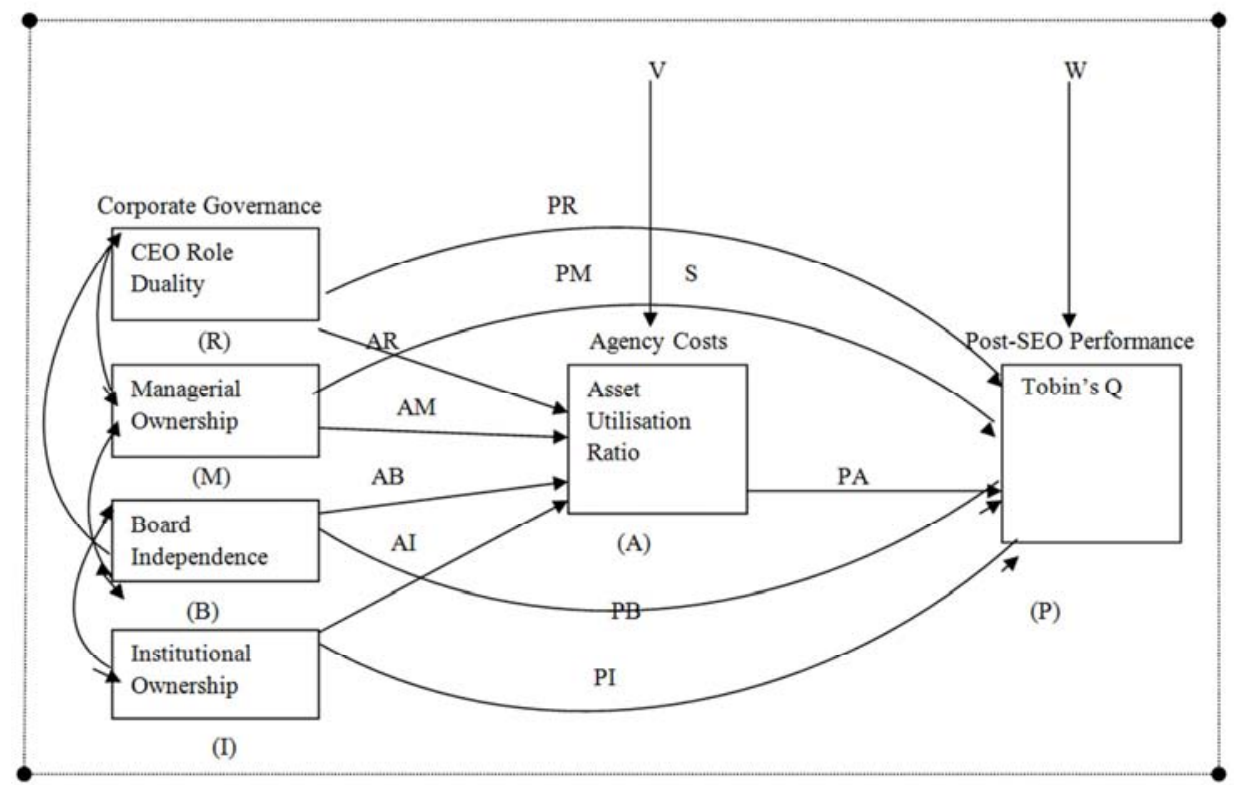

Source: Researcher's Model

Figure 1. Empirical Model.

The diagram also displays the hypothesised causal relationships among these 6 variables - CEO role duality, Managerial ownership, Board independence, Institutional ownership, Agency costs and Post-SEO performance.

The double headed arrows between CEO role duality, Managerial ownership, Board independence and Institutional ownership shows the co-variation among these exogenous variables.

\subsection{Structural Equation Model}

$$
\begin{gathered}
\mathrm{A}=\mathrm{P}_{\mathrm{AR}} \mathrm{R}+\mathrm{P}_{\mathrm{AM}} \mathrm{M}+\mathrm{P}_{\mathrm{AB}} \mathrm{B}+\mathrm{P}_{\mathrm{AI}} \mathrm{I}+\mathrm{P}_{\mathrm{AV}} \mathrm{V}- \\
\mathrm{P}=\left(\mathrm{P}_{\mathrm{AR}} \mathrm{R}+\mathrm{P}_{\mathrm{AR}} \mathrm{R} \mathrm{P}_{\mathrm{PA}} \mathrm{A}\right)+\left(\mathrm{P}_{\mathrm{AM}} \mathrm{M}+\mathrm{P}_{\mathrm{AM}} \mathrm{M} \mathrm{P}_{\mathrm{PA}} \mathrm{A}\right) \\
+\left(\mathrm{P}_{\mathrm{AB}} \mathrm{B}+\mathrm{P}_{\mathrm{AB}} \mathrm{BP} \mathrm{PA}_{\mathrm{PA}} \mathrm{A}\right)+\left(\mathrm{P}_{\mathrm{AI}} \mathrm{I}+\mathrm{P}_{\mathrm{AI}} \mathrm{I} \mathrm{P}_{\mathrm{PA}} \mathrm{A}\right)+\mathrm{P}_{\mathrm{AW}} \mathrm{W}-
\end{gathered}
$$

Where:

$\mathrm{R}=\mathrm{CEO}$ Role Duality

$\mathrm{M}=$ Managerial Ownership

$\mathrm{B}=$ Board Independence

$\mathrm{A}=$ Agency Costs
$\mathrm{P}=$ Post - SEO Performance

$\mathrm{V}=$ the unexplained variance that could not be explained by the variables in the model about agency costs

$\mathrm{W}=$ the unexplained variance that could not be explained by the variables in the model about post - SEO performance

\subsection{Theoretical Framework}

\subsubsection{Agency Theory}

It is an acknowledged fact that the principal-agent theory is generally considered as the starting position for any discuss on corporate governance emanating from the classical thesis on The Modern Corporation and Private Property by Berle and Means (1932) as cited in [1]. According to this thesis, the fundamental agency problem in modern firms is principally owing to the separation between finance and management. Modern firms suffer from a separation of ownership and control and therefore are run by professional managers (agents) who cannot be held accountable by dispersed shareholders. This view fits into the 
principal-agent paradigm. In this regard, the fundamental question is how to ensure that managers follow the interests of shareholders in order to reduce cost associated with principal-agent theory. The principals are confronted with two main problems. Apart from facing an adverse selection problem in that they are faced with selecting the most capable managers, they are also confronted with a moral hazard problem: they must give agents (managers) the right incentives to make decisions aligned with shareholder interests.

In further discussion of agency relationships and cost [49] describe agency relationship as a contract under which "one or more persons (principal) engage another person (agent) to perform some service on their behalf, which involves delegating some decision-making authority to the agent". In this scenario, there exists a conflict of interests between managers or controlling shareholders, and outside or minority shareholders leading to the tendency that the former may extract "perquisites" (or perks) out of a firm's resources and be less interested to pursue new profitable ventures.

Agency costs include monitoring expenditures by the principal such as auditing, budgeting, control and compensation systems, bonding expenditures by the agent and residual loss due to divergence of interests between the principal and the agent. The share price that shareholders (principal) pay reflects such agency costs. To increase firm value, one must therefore reduce agency costs.

\subsubsection{Information Asymmetry}

According to Myers and Majluf (1984) as cited in [16], public issue conveys to the market that management believes that the firm is overvalued. Since managers' have more information about the value of the firm than outside investors, firms may not issue equity to public as far as the proportion of existing assets transferred to the new shareholders are greater than the proportion of increased firm value retained by the existing shareholders. As a result of that information gap, investors face two choices when they make investment decisions in a company. First, they have to decide which firms have a good management team - this situation is called adverse selection. The second possible problem is moral hazard, which means that the managers do not use the extra information in pursuit of extravagant behaviour; or confirming that managers distribute dividends to shareholders rather than to employees or other groups. This could lead to over investing, which could be more influential than managers' perquisites and may result in reducing corporate performance. However, in the light of uncertainty and moral hazard, investors have to include the possible costs of these problems when they weigh up whether or not to invest in the investment opportunity [49]. Regardless of which choice the investors go with, this situation may negatively affect the cost of outside equity for companies.

In order for companies to reduce the impact of adverse selection and moral hazard, they have to adopt a good corporate governance system, which is considered a signal of the quality of a firm's management team.
Theoretically, complying with recommendations of corporate governance codes is fundamentally regarded as a good signal by companies toward markets and investors. This indicates that, because a company follows the best practices of corporate governance, investors will be assured that managers will act in the best interests of shareholders. This means that the investors will offer high prices for companies with a good corporate governance system, because the investment in such companies will be profitable [56]. For instance, adding more independent non-executive directors to the board is considered a signal to investors and markets that the company will improve its corporate governance to meet the expectations of investors. Also, the disclosure of such an event is likely to increase the share price, due to the demand for shares by investors in the market, and to reduce information asymmetry [16] [56] and consequent upon that, an increase in share prices is supposed to reduce the cost of outside equity (Botosan, 1997) cited in [75].

The theories discussed above will be used to underpin the study of the impact of corporate governance and performance of SEO firms with agency costs as a mediator.

\section{Literature Review, Variables and Research Hypotheses}

\subsection{Post-SEO Performance of Firms}

Among the first to demonstrate that returns to U.S. firms following SEOs are significantly lower than their non-issuing counterparts for up to five years are [64] and [87]. Large deal of the empirical research indicates that equity returns may perhaps exhibit negative effects after SEOs [3] [30] [6] [64].

Several research papers find that SEOs are poor investments during the window of $1-5$ years after the issuance in the U.S. market [64] as well as in the international markets [14] [47] and [65] find that industrial SEO issuers experience pre-issue run-ups and significant post-issue declines in operating performance in both unadjusted and industry-adjusted comparisons. [64] report that the financial multiples at the time of issuance, including profit margin and return on assets, do not reflect expectations of declining performance. Despite this, operating performance deteriorates following the SEO issuance.

The long-run underperformance of SEO firms has caught the attention of several researchers who have investigated the managers' incentives in equity-issuance decisions and assessed the post-issue performance. First, managers may exploit their private information with regard to either a stock over- valuation [69] or expectations of declining future earnings [67] and 64; [23]; potential internal and external certification mechanisms [54] Other studies include,[10]; [72]; [52]; [48]; [16] and [41]

Second, the agency theory of Jensen points out the diverging interests between shareholders and managers. In such a case, managers have strong incentives to make decisions and take on projects that maximize their private interests at the expense of the shareholders (Shleifer and 
Vishny, 1989 as cited in [42]). The misconduct of managers worsens if ample free cash flow is available: they are induced to invest the funds in negative NPV projects. Indeed, [66] find evidence that free cash flow is negatively related to postSEO performance.

\subsection{CEO Role Duality}

Agency theory suggests that a board of directors dominated by executive directors cannot be monitored. Such domination of executive directors can occur, for example, when one individual is appointed as both the CEO and board chairman, a phenomenon known as 'duality'. Duality can result in entrenchment of the CEO since, as chairman, the CEO has the ability to change the board's plans and facilitate access to necessary information. Thus, combining the roles of CEO and chairman not only results in entrenchment of the CEO but also limits the board's monitoring ability [75]. Therefore, duality is expected to have a negative impact on corporate performance. To ensure board independence, it is recommended that the functions of the CEO and chairman are split. Appointing different individuals to the positions of CEO and board chairman draws a clear boundary between the monitoring function of the nonexecutive directors and the operating function of the executive directors [32]. On the other hand, however, duality could improve corporate performance since it provides the firm with a CEO and chairman who have the knowledge and experience to make better decisions in a timely way.

[26] Documented that firms that are larger, have stronger governance and more able CEOs are more likely to combine CEO and board chair roles. They also document that firms that split these roles have significantly lower announcement and post-announcement returns, and lower contributions of investments to shareholder wealth. [76] Found no significant relationship between CEO duality and agency costs. He concluded that findings mean that, duality may have given the CEOs enormous powers; it may have reduced the check and balance or board's ability to exercise the governance (monitoring) function, which is not helpful to enhance firm efficiency.

Since the choice of leadership structure is a non - random decision, [89] employed a two-step procedure proposed by Heckman (1979) to investigate the role of external competition, board characteristics, and ownership structure on the choice of leadership structure, and to examine the relationship between dual-leadership structure and firm performance. The results show that the choice of leadership structure is endogenous.

[44] Examined CEO succession and CEO duality within the context of the balance of power among three central parties in the process: board of directors, incumbent CEO, and incoming CEO. Drawing on upper echelons thinking, they analysed the impact of board, incumbent CEO, and incoming CEO power on the appointment of the CEO to the position of board chair. He concluded that CEO duality is more likely to arise under conditions of outside CEO succession when the successor has prior chair experience and that tenure of the CEO predecessor reduces the likelihood of CEO duality. By means of an exogenous shock that increased competition, [96] Found that duality firms do better than nonduality firms by $3 \%$ when competition intensifies. The positive effect of having a dual leadership structure is larger when firms face higher information costs.

[73] Compared the moderating effects of CEO duality on the relationship between organizational slack and firm performance in China's state-owned enterprises and privateowned enterprises. Their findings suggest that there is a positive relationship between organisational slack and firm performance, and that CEO duality negatively moderates this relationship in state-owned enterprises, but positively in private-owned enterprises. [59] Presented a comprehensive analysis of board leadership structure of corporations in Guyana focusing on whether individual boards are duality or separately led. They concluded that evidence is certainly suggestive if it is not compelling that there is a substantive relationship between board leadership structure and business success in the market place of Guyana.

[90] Investigates the linkage between board leadership, firm financial performance (Tobin's Q) and agency costs (Sales to assets ratio) in MNC subsidiaries and LPCs in Sri Lanka. Applying the dynamic panel GMM method, they found that unitary leadership increase MNC subsidiaries financial performance and reduce agency conflicts. On the other hand, unitary leadership has no significant impact on LPCs financial performance. However, it positively affects agency conflicts in LPCs. [87] Investigated whether agency control mechanisms, agency problems, and other firm characteristics are related to the observed choice of one or two individuals in the two positions and the linkage between the CEO-Chair choice and the performance of the company and concluded that, results support the view that firm and management characteristics (such as the level of agency problems, information asymmetry, ownership structure, and the existence of other agency control mechanisms) influence the choice to split positions and influence the role and effectiveness of split positions.

[68] analysed the relationship between CEO duality and performance (ROA or ROE). His empirical findings indicate that the performance is negatively influenced if the manager President holds equities, which indicates that the respective person is more interested in maximising personal wealth at the expense of shareholders wealth maximisation. [92] Made an evaluation of the practice of CEO Duality in Nigeria and examined its implications on effective corporate governance and performance of Non-Financial companies in the Nigerian Stock Market. He uses panel data on the performances (ROE) of companies with CEO-Duality and those without CEODuality to determine the effect of the duality on company performance. He found a significant difference between the performances of companies with CEO duality and those without CEO duality.

[50] Investigated the impact of corporate governance characteristics on IPO firms' auditor choice in an emerging market setting. They utilised three corporate governance 
attributes - CEO-Chair duality, retained ownership, and foreign equity participation. Findings suggest that CEOChair duality and the degree of foreign equity participation are significant determinants of auditor choice while proportion of board ownership is not. [28] Examined the impact of CEO duality on the performance of firm for a sample of 204 listed firms on Istanbul Stock Exchange (ISE) between the years 2009-2010 in Turkey. Their results show that CEO duality has a negative impact on the firm performance, consistent with the agency theory.

Following the literature on CEO role duality we hypothesise as follows:

Hypothesis 1: There is a negative relationship between duality and corporate performance of SEO firms.

Hypothesis 2: Agency costs will be higher when there is CEO role duality.

\subsection{Managerial Ownership}

[2] Investigated why listed firms in China favour private placements compared to other options of raising capital. Ordinary least squares regression, piecewise regression and the cross-sectional regression analysis were undertaken to explore the determinants and characteristics of the seasonedequity offerings announcement effects. They found positive significant announcement abnormal returns for private placement. Their findings moreover point out that operating performance deteriorates immediately after announcement and poor operating performance is more likely to be contributed by large size portfolios, which suggests size effect.

[6] Examined the sensitivity of simultaneous equation techniques in corporate governance research. They model Tobin's Q, board composition and managerial ownership using a three equation instrumental variables approach with two specifications and four instruments. They found that variables are jointly determined. However, results depend strongly on the specification of the model and the instruments. They concluded that results using simultaneous equation methods must be interpreted with caution, while OLS estimates should not be casually dismissed and that sensitivity analysis is essential when estimating an empirical model whose structure is uncertain.

[14] Provided evidence that if equity is overvalued, still, mispricing offsets agency costs and can induce a controlling shareholder to list equity. Higher valuations support listings associated with greater agency costs. They investigated the predictions that follow from this idea on a sample of publicly listed corporate subsidiaries in Japan. They concluded that, when there is greater scope for expropriation by the parent firm, minority shareholders fare poorly after listing and parent firms frequently repurchase subsidiaries at large discounts to valuations at the time of listing and experience positive abnormal returns when repurchases are announced.

[19] Specified a simple structural model to isolate the economic determinants of managerial ownership and board structure in a value-maximizing contracting environment and jointly determined the optimal firm size, level of managerial ownership, and the proportion of outsiders on the board through the relative importance of the three productivity parameters of physical assets, managerial/insider effort and outside director's advising/monitoring role in the firm production process. Their model provides an equilibrium explanation for the cross-sectional relationships between managerial ownership, board structure, and firm performance that is consistent with existing evidence.

[23] Examined the short-term and long-term share-price behaviour surrounding the announcement of seasoned equity offerings (SEOs) by firms listed on the Athens Stock Exchange (ASE). We observed changes in leverage and systematic risk, as well as the long-term share price and operating performance of those firms involved in a SEO. They reported significant share-price appreciations on SEO announcement day. They additionally, found a share-price rally before the announcement of SEOs and subsequent share-price reversals. Furthermore, they document evidence that the long-term operating performance and the capital structure of firms announcing a SEO deteriorates for up to two years following the announcement. They concluded that their results suggest that corporate governance structures, dividend status, and ownership concentration enhance the information content of SEOs.

Using a two-equation model and a sample made up of 36 small-sized French firms, [29] studied the relationship between the managerial property and performance. He found that, the stake the managers hold is influenced by the profitability of the firm they manage. He concluded that, estimation results show that managerial ownership does not impact on performance and endogeneity is rejected.

[65] Investigates whether financial performance is a function of managerial ownership. It also searched whether managerial ownership is a function of performance. The major statistical result concerning financial performance is that it increases significantly with increasing managerial ownership. Moreover, managerial ownership is a significantly increasing function of the proxy for expected financial performance. Finally, the proxy for expected performance is a significant and positive function of current financial performance. He concluded that, there is strong evidence that managerial ownership as a motivating device is a function of financial performance and that there is some evidence that financial performance is better for firms in which the managers own at least $0.5 \%$ of the shares.

[17] Proposes a new measure which captures stock performance adjusting for risk in a single variable. The measure is general enough to apply to all risk-averse investors, irrespective of their utility function. Their findings suggest that low and high levels of managerial ownership hinder firm performance, while intermediate levels of managerial ownership enhance it. They concluded that, when individual moments of the firm's return distribution are used to measure performance they give conflicting results and that there is strong evidence that managerial ownership has a significant effect on firm performance that varies with the degree of ownership. 
[58] Identified the causal effect of managerial ownership on firm performance by exploiting the 2003 Tax Cut as a natural experiment, which increased the net-of-tax effective managerial ownership. Their empirical design uncovers a significant and hump-shaped improvement in firm performance with respect to the level of managerial ownership, which is consistent with predictions from agency theory. They concluded that the increase in performance is more pronounced for firms subject to more severe agency problems as well as firms under weak alternative governance mechanisms, which further demonstrates managerial ownership's incentive as the underlying channel for the results.

[79] Examined the influence of managerial ownership on firm performance through capital structure choices using examples of China's civilian-run listed firms from 2002 to 2007. The empirical results of OLS regressions on civilianrun listed firms replicate the nonlinear relationship between managerial ownership and firm value. Managerial ownership also drives the capital structure into a nonlinear shape, but with an opposite direction to the shape of managerial ownership on firm value. Furthermore, results of simultaneous regressions suggest that managerial ownership impacts capital structure, which in turn, affects firm value. They concluded that their results confirmed further the endogeneity of capital structure in China's civilian-run listed companies.

[33] Revisits the classical debate about the nature of the relationship between managerial ownership and corporate performance by using a semi-parametric estimation approach. According to them, the semi-parametric approach will help in avoiding the concerns that are related with the potential misspecification of parametric models and enables the consideration of a wider range of non-linear behaviors. Their empirical results support the existence of the initial alignment effect of managerial ownership at levels lower than $15 \%$, while they do not lead to a strong inference on the relationship between managerial ownership and corporate performance for intermediate and high levels of managerial ownership. They concluded that the results cast doubt on the findings of recent studies on the subject, which critically rely on fully parametric methods, and instead suggest the use of semi- parametric methods in estimating the shape of the ownership-performance curve.

[80] Found that managers are more likely to significantly decrease their ownership when their firms are performing well, but not more likely to increase their ownership when their firms have poor performance. Because investors learn about the total change in managerial ownership with a lag, changes in Tobin's q in a period can be affected by changes in managerial ownership in the previous period. In an efficient market, it is unlikely that changes in managerial ownership in one period are caused by future changes in $\mathrm{q}$. When controlling for past stock returns, they further found that large increases in managerial ownership increase $q$. According o them the result is driven by increases in shares held by officers, while increase in shares held by directors appear unrelated to changes in firm value. They concluded that, there is no evidence that large decreases in ownership have an adverse impact on firm value and argued that their evidence cannot be totally explained by existing theories and propose a managerial discretion theory of ownership consistent with the evidence.

[54] Examines the relationship between managerial share ownership (MSO) and firm performance of Australian firms during the period 2000 to 2003 . They did not find any evidence of non linear relationship between MSO and Tobin's Q but found significant negative relationship between MSO and Tobin's Q using simple linear regression model. According to them the results were found after controlling for endogeneity.

[35] Utilised panel data for seventeen (17) firms for the period $2001-2010$ and examined the impact of ownership structure on the financial performance of listed insurance firms in Nigeria. They observed that despite the several aspects and dimensions of corporate governance, which may influence a firm's performance but they chose to focus on two aspects of ownership structure - managerial and institutional shareholding. They measured firm's performance through Return on Asset (ROA) and Return on Equity (ROE). They found a positive significant relationship between ownership structure and firm's performance as measured by ROA and ROE. They concluded that the code on owner's equity of listed insurance companies should be sustained and encouraged so that the firms can have a perpetual life, because the stake of this owners could serve as a check and balance mechanism to further strengthen the corporate governance of the insurance firms in order to give room for enhanced financial performance of the listed insurance companies in Nigeria.

Examining a sample of non-listed Chinese firms, [40] provided the first evidence from China for the effect of managerial ownership on firm performance. They used a matching-sample comparison and found that firms of significant managerial ownership outperform firms whose managers do not own equity shares. Their results further indicate that the relationship between firm performance and managerial ownership is non- linear, and the variation point at which the relation turns negative occurs when ownership goes beyond $50 \%$. They concluded that their results are less likely to suffer from an endogeneity problem considering their use of non-listed firm's sample and the unique institutional environment in China.

[40] Utilised panel data to show that managerial ownership is explained by key variables in the contracting environment in ways consistent with the predictions of principal-agent models. Their results show that a fraction of the crosssectional variation in managerial ownership is explained by unobserved firm heterogeneity. After controlling for observed firm characteristics and firm fixed effects, they cannot econometrically conclude that changes in managerial ownership affect firm performance.

Hypothesis 3: There is positive relationship between Managerial ownership and SEO firm performance. 
Hypothesis 4: Agency costs will be lower when there is higher level of Managerial ownership

\subsection{Board Independence}

Paying particular attention on the relationship between corporate board independence and firm financial performance in Nigeria, [84] found that share ownership is highly concentrated in Nigeria and this structure tend to bring about board structures with close family affiliations and in which the CEO tends to take an active part in membership of audit committees. Whereas family affiliation of board members is found to support firm growth, evidence shows that audit committee membership of chief executives hurts firm performance. They further found that foreign chief executive perform better than their local counterparts. [82] Also found that larger board independence is perceived as a monitoring mechanism which can play an important role in limiting or controlling the agency problem.

[63] Found that independent directors have a generally positive effect on firm operating performance in China. They further document that Chinese independent directors play an important role in constraining insider self-dealing and improving investment efficiency. [46] Focuses on whether board independence explains stock price reactions to backdating and factors that explain backdating decision. Their findings show negative stock returns around backdating news. Even though findings show that board independence variables fail to explain the incidence of backdating, their regression results however, show that stockholders consider these variables to be important.

Using American public companies, [7] shows that firms suffering from low profitability respond by increasing the independence of their board of directors, but there was no proof that the strategy that firms with more independent boards achieve improved profitability actually works.

[62] Utilised a longitudinal sample of 1,143 firms in the S\&P 1500 list from 1997 through 2006 and investigated the relationship between board independence and firm's longterm performance, as measured by Tobin's Q. He found some evidence of a significant nonlinear relationship. [97] Investigated how board independence affects a board's monitoring intensity and the CEO pay disparity. Results suggest that the trends of CEO pay disparity can be partly explained by the trends in the nature of board independence.

[77] Found significant positive effect of board size on both market based and accounting based performance measures and significant negative effect of insider ownership on ROA, while board independence has significant positive impact on market based performance measures. [71] Results showed a statistically significant negative relation between board size and performance. Furthermore, a statistically significant positive relationship was found between the proportion of independent directors on the bank board and performance of the bank.

[98] Found that the proportion of independent directors on board is significantly positively associated with firm performance only when the firm performance is adjusted for the effect of earnings management. Related results are found in ownership concentration. [19] Used a simple structural model to isolate the economic determinants of managerial ownership and board structure in a value-maximizing contracting environment. The optimal firm size, level of managerial ownership, and the proportion of outsiders on the board is jointly determined by the relative importance of the three productivity parameters of physical assets, managerial/insider effort and outside director's advising/monitoring role in the firm production process. Their model provides an equilibrium explanation for the cross-sectional relationships between managerial ownership, board structure, and firm performance that is consistent with existing evidence. They used the model to provide an alternative explanation for the observed changes in compensation structure arising from new rules mandating changes in board independence following the Sarbanes Oxley act in 2002 .

As there were no consistence relationship between board independence and firm performance, hence, we hypothesize as follows:

Hypothesis 5: There is a positive relationship between board independence and the performance of SEO firms.

Hypothesis 6: Agency costs will be lower when firms have higher board independence.

\subsection{Institutional Ownership}

A large body of research has focused on the role of institutional investors as corporate monitors. The rationale is that due to the high cost of monitoring, only large shareholders such as institutional investors can attain sufficient benefits to have an incentive to monitor. Institutional investors have become important players in today's financial markets. Their increasing importance in corporate governance is observed from the growing volume of corporate equity they control. According to Hayashi (2003) cited in [22], in the US, for example, institutional investors were estimated to control $60 \%$ of all outstanding equity in 2003 compared to $45 \%$ in $1990,33 \%$ in 1980 and $8 \%$ in 1950 (Taylor, 1990, cited in Charfeddine \& Elmarzougui, 2010). The observed increase in Institutional Ownership (I) in the equity market has been attributed to the growth in pension funds (Graves and Waddock, 1990, cited in [22]. Accompanying the growing volume of institutional shareholdings in the equity market, the role of institutional investors has changed dramatically from that of simply passive investors to active monitors.

Conventionally, institutional investors are not directly concerned with corporate management decisions; as an alternative, they merely exit by means of selling their stakes as soon as they are not satisfied with the management of the organization or else if share price falls. With increasingly significant ownership of equity invested in a firm, it has become less costly for institutions to 'voice' disagreement with the management instead of following an 'exit policy' and depressing the firm's stock price (Coffee, 1991 as cited in [30]). 
Institutional investors, compared to other non-institutional investors are more likely to engage in corporate management decisions due to their significant ownership of equity in the firms (Brickley et al., 1998 as cited in [33]) and attempt to influence top firm management to manage long-term interests of shareholders (Holderness and Sheehan, 1988 cited in [33]). In other words, institutional investors may possibly have assumed a more valuable role of monitors in the corporate governance ground. As a result, they may perhaps further influence top-management decisions and consequently, firm performance.

[3] Found that greater institutional ownership is associated with more innovation. [9] Investigates the relationship between different classes of institutional investors and firm performance. Their empirical results suggest a significant two-way feedback between firm performance and institutional equity ownership, though, the effect is not symmetric. They concluded that institutional investors with possible investment and business ties with firms have adverse effect on firm performance and the impact is very significant in comparison to the negative effect of firm performance on institutional ownership. [22] Examines the relationship between institutional ownership and firm performance for 35 companies listed on the French financial market from 2002 to 2005. They used Tobin's Q in a simultaneous equation system as a measure of firm performance and their results provide evidence that institutional ownership has a significant negative impact on the performance of firms.

In a similar study, [20] examines the link between institutional investor involvement in and the operating performance of large firms. Their results show a significant relationship between firms' operating cash flow returns and both the percent of institutional stock ownership and the number of institutional stockholders. [44] Found that firms with more short-term institutional shareholders experience significantly more negative abnormal returns at the announcement of seasoned equity offerings. [82] Investigated the relationship between institutional ownership and firm performance. Their results internationally uphold previous findings of a positive impact of institutional activism on firm performance. [30] Investigated the relationship between corporate firm performance and the level and stability of institutional ownership within a simultaneous equation model. Results show a positive relationship between firm performance and institutional ownership stability, taking into account the proportion of shareholding.

[25] Examined the impact of institutional ownership on share price and operating performance following seasoned equity offerings. They found that announcement returns are positively and significantly related to total and active institutional ownership levels and concentration. Post-issue stock returns are also found to be positively and significantly related to the contemporaneous post-issue changes in total and active institutional ownership and the concentration of their shareholdings. Furthermore, operating performance improvements are also found to be related to institutional monitoring in the one, two, and three years following the equity issue.

Following the literature on institutional ownership we hypothesise as follows:

Hypothesis 7: There is a positive relationship between institutional ownership and performance

Hypothesis 8: Agency costs will be lower at higher level of institutional ownership.

\subsection{Agency Costs}

Jung et al. (1996), cited in [30] argue that agency problems related to managerial discretion are the most powerful in explaining the decision to issue equity over debt. They show that a large percentage of equity issuers have poor investment opportunities. Even when their debt capacity is not exhausted, they issue equity and forego the issuance of debt - which would be more enhancing for the firm's value. Fields and Mais (1994), cited in [30] also find a negative relationship between the announcement stock returns of SEOs and management entrenchment (as measured by the increase in managerial control of voting rights). In the same vein [83] utilised stock price reaction to unexpected senior executive deaths to study managerial entrenchment. He concludes that proposed good governance practices, particularly a high percentage of outside directors in the board, are helpful but not always effective in preventing managerial entrenchment. Similarly, Berger et al. (1997), cited in [83] suggest that the tendency to avoid debt correlates with CEO entrenchment reflected in loose pressure from ownership and compensation incentives, as well as weak monitoring.

The influence of agency problems on SEO issuance is also reflected in the earnings' management practiced by managers prior to the offer. Teoh et al. (1998) and Rangan (1998), cited in [30] found that the tendency of managers to borrow against future returns and inflate current earnings prior to the issue negatively correlates with post-issue performance. Similarly, According to Jensen $(2004,2005)$, cited in [83] the earnings' management could be due to the agency costs of overvalued stock which induce managers to inflate earnings in order to keep up with the expectations of investors and analysts. Thus, managers often exploit investors to create illusory value creation and/or issue shares at premium prices. To conclude, the decision to issue equity and the subsequent underperformance are often perceived to be driven by severe agency problems related most notably to free cash flow, stock overvaluation, and earnings' management.

Nevertheless, we are unaware of any published study that examines the role of corporate governance measures in SEO decisions or on the post-issue performance. On the other hand, the corporate governance literature clearly shows that corporate governance structures and mechanisms mitigate agency problems since they allow the boards of directors to better supervise managers' decisions (Ching et al., 2002) cited in [83] prevent management entrenchment (Gompers et al., 2003), cited in [82] improve earnings' management (Niu, 2006, and Leuz et al., 2003) cited in [82] and hold an overvalued stock (Jensen, 2004, 2005) cited in [83]. 
Consequently, good (bad) corporate governance mechanisms are positively associated with positive (negative) stock returns and operating performance as has been shown in the mergers and acquisitions context after announcement [24].

Singh and Davidson III (2003), cited in [24] determine that management ownership can significantly decrease agency conflict by increasing their asset utilization rate and reducing discretionary costs. Lins (2003) cited in [24] confirmed that agency costs can be effectively reduced through external shareholder protection mechanisms. Davidson, Bouresli, and Singh (2006) cited in [24] find that companies with strict market supervision and complete accounting transparency can reduce the occurrence of agency problems. Wang et al. (2006) cited in [93] support the agency theory in the sense that book-building offers a mechanism to strengthen external monitoring provided by block-holders, thereby reducing agency costs.

Similarly, [74] examined the influence of Mexico's efforts to improve corporate governance on firm performance and transparency. Utilising compliance data from the Code of 'Best' Corporate Practices, disclosed annually by public firms in Mexico, as a measure of corporate governance strength, they document significant increase in compliance over 2000-2004 indicating Mexican companies view noncompliance as costly. Though, no association existed between the governance index and firm performance, nor is there a relation with transparency. Alternatively, firms with greater compliance resort to the more costly mechanism of making dividend payments to reduce agency conflict.

Using 70 Non - financial listed firms on Karachi Stock Exchange from 2006 - 2010 [86] found that corporate governance has significant effect on firm performance under transaction cost economics theory and good corporate governance theory. They further found that corporate governance has significant effect on the value of firm and has a mediating effect in between the corporate financial structure and firm value. They concluded that the negative relationship shows an agency problem.

In a more recent study, [42] applied the analysis of moment structure (AMOS) setting, investigates the effectiveness of external corporate governance in mitigating agency costs and enhancing long-term operating performance for seasoned equity offerings. Hypothesising the crucial and mediating role of agency costs in the relationship between governance structure and post-SEO operating performance, the study reveal that the mediating role of reducing agency costs is crucial to the causal relationship between external corporate governance and post-SEO performance, indicating that external corporate governance can enhance performance through direct positive influence on firm performance and, more significantly, through indirect negative influence to decrease agency costs.

Following the literature, we hypothesise as follows:

Hypothesis 9: Agency costs mediate the relationship between corporate governance and performance

\subsection{Summary}

The literature review shows that a significant body of theoretical and empirical literature in accounting and finance had considered the relations among corporate governance, management turnover, corporate performance, corporate capital structure, and corporate ownership structure and firm performance. Similarly a lot has been documented on the performance of SEO firms before and after the event. But virtually all the studies investigated direct relationships. As earlier stated, there was only one study from U. S. that investigated through a mediating variable. That study used institutional ownership, auditor reputation and analyst coverage which are all external corporate governance variables. Hence, an investigation into the relationship between corporate governance on the performance of firms using a combination of variables of both internal and external corporate governance and to also use agency costs as a mediator is viable.

\section{Research Methods}

In an AMOS setting, this study first employs confirmatory factor analysis (CFA) to obtain the representative observable variables for each latent variable and to establish a completely fit model. Then, we proceed with the analyses of direct and mediating effects among latent variables.

\subsection{The AMOS (SEM) Setting}

Joreskog and Sorbom (1993) cited in [42] point out that with multi co-linearity among independent variables, SEM analysis is a more valid method for estimating a model than a simple regression method. It simultaneously solves correlations between a series of multiple independent and dependent variables and considers increasing vital causal paths through the appropriate measurement model or the level of fitness of the measurement model. When compared to general regression models, SEM structure (as does AMOS) can use measurement variables to assess latent variables that are difficult to observe directly, while identifying the relationship between each latent and measurement variable.

The total effect of an independent variable on the dependent variable can be divided into two parts: 2) the indirect effect that refers to the independent variable's effect on the dependent variable through a mediating variable, and 2) the direct effect that refers to the independent variable's effect on the dependent variable after controlling for the indirect effect [42] According to MacKinnon, Lockwood, Hoffman, West, and Sheets (2002) and Preacher and Hayes (2004) cited in [42], the mathematically formulated Sobel test should first be used to determine whether the indirect effect is significant to adhere more closely to the meaning of mediating effect. In the Sobel test, a mediating effect exists when the $\mathrm{Z}$ value in the following equation is greater than 1.96:

$$
\mathrm{Z}=\mathrm{a} * \mathrm{~b} / \mathrm{SE}_{\mathrm{ab}}
$$


Where $a$ and $b$ are non-standadisation values and $\mathrm{SE}^{2} \mathrm{a}^{2}$ and $\mathrm{SE}^{2} \mathrm{~b}^{2}$ are standard errors of $a$ and $b$.

\subsubsection{Confirmatory Factor Analysis (CFA) and Measurement Reliability}

This study will perform a CFA on the relevant variables to test the representativeness of the latent variables and to establish the complete fit for the research model. The CFA will be conducted on corporate governance, agency costs, and operating performance in order to eliminate inefficient observation from variables and to ensure that each factor complied with the optimum fit indicators.

Micceri (1989) cited in [42] indicated that when the SEM method is used to analyze data, data must be corrected and transferred in violation of the normality assumption to ensure reliability. To avoid the trouble of negative definition in the SEM model, we will refer to the practice of Abarbanell and Bushee (1998) cited in [42]. Following [42] this study will adjust the scales and units of different observed variables, sort the raw data into deciles, and then converted data will range from 1-10. Chou, Bentler, and Satorra (1991) and $\mathrm{Hu}$ and Bentler (1995) cited in [42] point out that when the multivariate normal assumption does not hold, the standard errors and $t$ values of the parameters estimated in a SEM model will be biased leading to estimated results with significant distortions. According to Gilford (1954) cited in [42], Cronbach's $\alpha$ is used to indicate the measurement reliability. Reliability is high when the indicator is greater than or equal to 0.70 , acceptable when the indicator is from $0.35-0.70$, and low when the indicator is less than 0.35 .

\subsubsection{Goodness-of-Fit Measurement}

An overall goodness-of-fit test will be conducted to evaluate the suitability of the model. Goodness-of-fit is a model quality test that is used to examine whether the empirical results are consistent with the theoretical model. The evaluation criteria are broadly divided into absolute fit indices, comparative fit indices, and parsimonious fit indices. The absolute fit measures include the chi-square test (x2), the standardized root mean square residual (SRMR), the root mean square error of approximation (RMSEA), the goodness-of-fit index (GFI), and the adjusted goodness-of-fit index (AGFI)

The comparative fit measures include the normed fit index (NFI), the non-normed fit index (NNFI), the incremental fit index (IFI), the comparative fit index (CFI), and the relative fit index (RFI). The parsimonious fit measures include the parsimonious normed fit index (PNFI), the parsimonious goodness-of-fit index (PGFI), and Hoelter's critical N (CN).

\subsection{Measures}

\subsubsection{Corporate Governance (CG): Independent Variable}

The study will use the following explanatory variables to measure corporate governance: 1) CEO role duality, 2) CEO ownership, 3) Board independence, and 4) Institutional ownership.

\subsubsection{CEO Role Duality (R)}

Following [82] duality is included as a dummy variable which is given a value of 1 if the CEO is also the chairperson of the board of directors and 0 otherwise. We assume that agency costs will be lower when companies have two different persons acting as a CEO and chairperson. Agency theory supports the idea that the role of the chairman should be separated from that of the CEO to ensure that the later would not be in a position with too much power to handle daily business operations. That is, CEO with excessive power over board could easily manipulate income [4].

\subsubsection{Board Independence (B)}

Following [82] it is measured as the number of independent directors on the board relative to total number of board members. We assume that companies will face lower agency costs when they have higher board independence. Agency theory supports the idea that board independence should be denominated by outside directors ([4]).

\section{$\mathrm{B}=$ No. of independent Directors $\div$ No. of Board of directors $\times 100$}

\subsubsection{Managerial Ownership (M)}

Following [58] Managerial ownership will be measured as the percentage of total shares held by firm directors and officers.

\section{$M=$ No. of shares owned by firm Directors and Officers : No. of outstanding shares $\times 100$}

\subsubsection{Institutional Shareholding (I)}

Pound (1988) cited in [42] finds that institutional investors are well suited to provide the professional expertise, technology, and costs required for monitoring management. Economies of scale allow them to spend fewer resources on monitoring as compared to minority shareholders [42]. Therefore, increasing institutional shareholdings can efficiently decrease the agency problem and improve corporate operating performance. O'Brien and Bhushan (1990) cited in [42] suggest that a greater number of shareholdings owned by institutional investors enhance performance. Following [42] institutional ownership (I) will be measured as the percentage of shares held by institutional investors at the end of the year.

\subsection{Agency Costs (A): Mediating Variable}

Agency costs resulting from bonding activities are contractual limitations on the manager's decision-making power [42]. Agency costs ensuing from monitoring consist of auditing, formal control systems, budget restrictions, and incentive compensation systems. In addition, some residual loss, which is the effective loss, related to the statecontingent future of the firm, results despite the bonding and monitoring costs incurred. The sum of the monitoring, bonding and residual costs is the agency cost. Following [5] and [82] asset utilisation ratio will be used to measure agency costs. A higher asset utilisation ratio indicates that companies 
are making investment decisions which are non-optimal or a second interpretation will be that companies are investing their funds in projects which are unproductive. Asset utilisation ratio is defined as total revenue/total assets.

\subsection{Post-SEO Performance (P)}

Following [69] Performance will be measured in terms of Tobin's Q which represent the ratio of market capitalization to book value of assets for firm $i$ in period $t$. This too represents financial performance of firms listed at the Nigeria stock exchange.

The variable is defined thus:

Tobin's Q = Market value of common stock + Book value of long-term debt $\div$ Book value of total assets of the company.

The choice of this performance measure is motivated by the fact that this indicator give good interpretations regarding firm's performance as proposed by Mesquita and Lara (2002) cited in [69]. According to Cole and Mehran (1998) cited in [69] for a study of this nature to have a solid base as well as in contour with earlier studies, it is essential to pick measures of performance that are quantifiable, expressive and comparable. The study will therefore, use this measure of performance since it met these three attributes.

\subsection{Sample and Data}

The sample that will be used for this study will comprise of SEOs in Nigeria from 2006-2015 which will be obtained from Nigeria Securities and Exchange Commission (SEC), Nigerian Stock Exchange (NSE) and Cash-Craft Asset Management Company databases. The sample period will end in 2013. This is to allow for the availability of operating and stock data for the post-SEO period. Consistent with previous research, the following observations will be excluded from the final sample: 1) issuing firms from the financial insurance industry, 2) SEOs within a three-year period after listings and 4) issuing firms with insufficient data.

\section{Conclusion}

The post-SEO poor performance of firms has fascinated researchers. The aim of this study is to take into account a variety of corporate governance factors, to adopt AMOS while analysing the power of corporate governance on the underperformance of SEO firms as well as in determining whether agency costs subsist as a mediating variable among them. The advancement of corporate governance mechanisms are anticipated to decrease agency costs after SEO's through aligning interests in addition to mitigating the harmful effects of increasing agency costs on firm performance. This research will investigate the direct effect of corporate governance on agency costs and the influence of corporate governance on firm performance. The study will then examine the mediating effect of reducing agency costs on the influence of corporate governance on performance. The use of the mediator is to test the existence of poor administrative mitigating functions of corporate governance in the reduction of agency costs. Our research will be the first study to investigate the mediating effect of agency costs on the relationship between corporate governance and SEO performance. Specifically, the study is aimed at investigating whether agency problem is critical while explaining the decline in SEO firms operating performance. The study will as a result, expand the research frontiers for corporate governance, SEOs underperformance, and agency theory; and demonstrate what value better corporate governance can add to shareholders wealth in the issuing context.

\section{References}

[1] Abbasi, M., Kalantari, E., \& Abbasi, H. (2012). The Impact of Corporate Governance on Chief Executive Officer ( CEO ) Duality in Iranian Banking Sector. Kuwait Chapter of Arabian Journal of Business and Management Review, 2(1), 1-9.

[2] Abidin, S., Reddy, K., \& Chen, L. (2012). Determinants of ownership structure and performance of seasoned equity offerings: Evidence from Chinese stock markets. International Journal of Managerial Finance, 8(4), 304-331. doi:10.1108/17439131211261242.

[3] Aghion, P., Reenen, J. V. and Zingales, L. (2009). Innovation and Institutional Ownership. American Economic Review, 103(1), 277-304. http://doi.org/10.1257/aer.103.1.277.

[4] Al-attar, A. (2012). Corporate Governance and Earnings Management: Jordanian Evidence, 5(1), 216-225. doi:10.5539/ibr.v5n1p216.

[5] Ang, J.S., R.A. Cole, and J.W. Lin, 2000, “Agency Costs and Ownership Structure,” Journal of Finance 55, 81-106.

[6] Barnhart, S. W., \& Rosenstein, S. (1998). Board conposition, managerial ownership, and firm performance: An empirical Analysis. The Financial Review, 33, 1-16.

[7] Bhagat, S., \& Black, B. (2000). Board Independence and Long-Term Firm Performance. Social Science Research Network Electriconic Journal, 2000(February), 1-44. http://doi.org/10.2139/ssrn.133808.

[8] Bhagat, S., \& Bolton, B. (2008). Corporate governance and firm performance. Journal of Corporate Finance, 14, 257273. doi: $10.1016 /$ j.jcorp.

[9] Bhattacharya, P. S., \& Graham, M. (2007). Institutional Ownership and Firm Performance: Evidence from Finland. Working Paper, 1-33. http://doi.org/10.2139/ssrn.1000092

[10] Bo, H., Huang, Z., \& Wang, C. (2011). Understanding seasoned equity offerings of Chinese firms. Journal of Banking \& Finance, 35(5), 1143-1157. doi:10.1016/j.jbankfin.2010.09.025.

[11] Bodunde, O., Rosemary, O. \& Soetan, O. (2015). Competition, corporate governance and corporate performance: Substitutes or complements? Empirical evidence from Nigeria. African Journal of Economic and Management Studies, 6(3), 251 - 271. doi:DOI 10.1108/AJEMS-02-2012-0007.

[12] Boone, A. L., \& White, J. T. (2015). The effect of institutional ownership on firm transparency and information production. Journal of Financial Economics, 117(3), 508-533. doi:10.1016/j.jfineco.2015.05.008. 
[13] Bushman, R., J. Piotroski, and A. J. Smith, 2004, "What Determines Corporate Transparency?" Journal of Accounting Research 42(2), 207-252.

[14] Chernenko, S., Greenwood, R. and C. F. F. (2010). Agency Costs, Mispricing, and Ownership Structure Sergey Chernenko. NBER Working Paper No. 15910, 1-50.

[15] Chi, J.D. and S. D. Lee, 2010, "The Conditional Nature of the Value of Corporate Governance," Journal of Banking and Finance 34, 350-361.

[16] Clarke, Jonathan, Dunbar, Craig and Kahle, K. M. (2001). Long-Run Performance and Insider Trading in Completed and Canceled Seasoned Equity Offerings. Journal of Financial and Quantitative Analysis, 36(4), 415-430. doi:10.2307/2676218.

[17] Clark, E., Belghitar, Y., \& Kassimatis, K. (2011). Managerial ownership and firm performance: A re-examination using marginal conditional stochastic dominance. Online Journal, $1-40$.

[18] Clark, E., Belghitar, Y., \& Kassimatis, K. (2011). Managerial ownership and firm performance: A re-examination using marginal conditional stochastic dominance. Online Journal, $1-40$.

[19] Coles, J. L., Lemmon, M. L., \& Wang, Y. A. (2008). The Joint Determinants of Managerial Ownership, Board Independence, and Firm Performance. Working Paper, Arizona State University, (852). Retrieved from http://ssrn.com/abstract=1089758

[20] Cornett, M. M., Marcus, A. J., Saunders, A., \& Tehranian, H. (2007). The impact of institutional ownership on corporate operating performance. Journal of Banking and Finance, 31(6), 1771-1794. doi:10.1016/j.jbankfin.2006.08.006.

[21] Craswell, A.T., S.L. Taylor, and R.A. Saywell, 1997, "Ownership Structure and Corporate Performance: Australian Evidence,” Pacific-Basin Finance Journal 5(3), 301-323.

[22] Charfeddine, L., \& Elmarzougui, A. (2010). Institutional Ownership and Firm Performance: Evidence from France. The IUP Journal of Behavioral Finance, VII(4), 35-46.

[23] Dasilas, A., \& Leventis, S. (2013). Corporate Governance, Dividend Status, Ownership Structure, and the Performance of Greek Seasoned Equity Offerings. International Journal of the Economics of Business, 20(3), 387-419.

[24] Dbouk, W., \& Ismail, A. (2010). Corporate governance and long run performance of seasoned equity issuers. Journal of Multinational Financial Management, 20(4-5), 159-177. doi:10.1016/j.mulfin.2010.08.001.

[25] Demiralp, I., Mello, R. D., Schlingemann, F. P., \& Subramaniam, V. (2011). Are there monitoring benefits to institutional ownership? Evidence from seasoned equity offerings Are there monitoring benefits to institutional ownership ? Evidence from seasoned equity offerings. Journal of Corporate Finance, Forthcoming, 48.

[26] Dey, A., Engel, E., \& Liu, X. (2011). CEO and board chair roles: To split or not to split? Journal of Corporate Finance, 17(5), 1595-1618. http://doi.org/10.1016/j.jcorpfin.2011.09.001

[27] Dharmastuti, C., \& Wahyudi, S. (2013). The Effectivity of Internal and External Corporate Governance Mechanisms
Towards Corporate Performance. Research Journal of Finance and Accounting, 4(4), 132-140.

[28] Doğan, M., Elitaş, B. L., Ağca V., \& Ögel, S. (2013). The Impact of CEO Duality on Firm Performance: Evidence from Turkey. International Journal of Business and Social Science, 4(2), 149-155. Retrieved from http://www.ijbssnet.com/journals/Vol_4_No_2_February_201 3/16.pdf

[29] Dufour, F. T. and D. (2011). Managerial Ownership and Performance: a Simultaneous-Equation Model. Journal of Business Studies Quarterly, 3(1), 300-310.

[30] Elyasiani, E., \& Jia, J. (2010). Distribution of institutional ownership and corporate firm performance. Journal of Banking and Finance, 34(3), 606-620. http://doi.org/10.1016/j.jbankfin.2009.08.018

[31] El-Faitouri, R.(2014). Board of Directors and Tobin's Q: Evidence from U.K. Firms. Journal of Finance and Accounting, 2(4), 82-99. Available online at http://pubs.sciepub.com/jfa/2/4/2 Science and Education Publishing DOI: 10.12691/jfa-2-4-2.

[32] Ferreira, D., Ferreira, M. a., \& Raposo, C. C. (2011). Board structure and price informativeness. Journal of Financial Economics, 99(3), 523-545. doi:10.1016/j.jfineco.2010.10.007.

[33] Ferreira, M. A., \& Laux, P. A. (2010). Corporate Boards and SEOs: The E ff ect of Certi fi cation and Monitoring. In 2008 European Finance Association Meetings, ISCTE (pp. 1-47).

[34] Florackis, C., Kostakis, A., \& Ozkan, A. (2009). Managerial ownership and performance. Journal of Business Research, 62(12), 1350-1357. http://doi.org/10.1016/j.jbusres.2008.12.001

[35] Gesser, R., Halman, R., \& Sarig, O. (2005). Measuring the agency costs of dispersed ownership: The case of repurchase initiations. Corporate Ownership and Control, 11(February), $1-40$.

[36] Gugong, B. K., Arugu, L. O., \& Dandago, K. I. (2014). The Impact of Ownership Structure on the Financial Performance of Listed Insurance Firms in Nigeria. International Journal of Academic Research in Accounting, Finance and Management Sciences, 4(1), 409-416. http://doi.org/10.6007/IJARAFMS/v4-i1/698

[37] He, W., Li, D., Shen, J., \& Zhang, B. (2013). Large foreign ownership and stock price informativeness around the world. Journal of International Money and Finance, 36, 211-230. doi:10.1016/j.jimonfin.2013.04.002.

[38] Hermalin, B.E. and M.S. Weisbach, 2003, "Boards of Directors as an Endogenously Determined Institution: A Survey of the Economic Literature," Economic Policy Review 9, 7-26.

[39] Himmelberg, C.P., R.G. Hubbard, and D. Palia, 1999 , "Understanding the Determinants of Managerial Ownership and the Link Between Ownership and Performance," Journal of Financial Economics 53(3), 353-384.

[40] Hu, Y., \& Zhou, X. (2008). The performance effect of managerial ownership: Evidence from China. Journal of Banking and Finance, 32(10), 2099-2110. http://doi.org/10.1016/j.jbankfin.2007.12.047. 
[41] Hubbard, R. G., Agrawal, A., Baker, G., Bhattacharya, S., Bond, S., Calomiris, C., ... Palia, D. (1999). Understanding the determinants of managerial ownership and the link between ownership and performance. National Bureau of Economic Research. Journal of Financial Economics (Vol. 53). http://doi.org/10.1016/S0304-405X(99)00025-2

[42] Huang, C.-W., Ho, P.-H., Lin, C.-Y., \& Yen, J.-F. (2014). Firm age, idiosyncratic risk, and long-run SEO underperformance. International Review of Economics and Finance, 34, 246-266. doi:10.1016/j.iref.2014.08.009.

[43] Huang, R. and Tompkins, J. G. (2009). Corporate Governance and Investor Reactions to Seasoned Equity Offerings. Online Journal. Retrieved from http://ssrn.com/abstract=1433359

[44] Hao, G. Q. (2014). Institutional Shareholder Investment Horizons and Seasoned Equity Offerings. Financial Management, 43, 87-111. http://doi.org/10.1111/fima.12038

[45] Horner, S., \& Valenti, A. (2012). CEO duality: How the Balance of Power within a Firm affects the Decision to Name a Newly Appointed CEO as Chair. Journal of Leadership, Accountability ..., 9(3), 53-75. Retrieved from http://www.nabusinesspress.com/JLAE/horner93_abstract.html

[46] I., B., \& Ehikioya. (2014). Corporate governance structure and firm performance in developing economies: evidence from Nigeria. The International Journal of Business in Society, 9(3), 231 - 243. doi:10.1108/14720700910964307.

[47] Iqbal, Z., Wang, K., \& O, S. (2009). Board independence and market reactions around news of stock option backdating. Journal of Economics and Finance, 35, 104-115. http://doi.org/10.1007/s12197-009-9109-z

[48] Javeed, A., Muhammad, R., \& Yaqub, S. (2015). An Empirical Examination of the Impact of Corporate Governance Measures and Capital Structure on Firm Profitability in Pakistan. Research Journal of Finance and Accounting, 6(13), 9-17.

[49] Jegadeesh, N. (2000). Long-Term Performance of Seasoned Equity Offerings: Benchmark Errors and Biases in Expectations. Financial Management (Wiley-Blackwell), 29, 5-30. doi:10.2307/3666227.

[50] Jensen, M.C. and M. Meckling, 1976, "Theory of the Firm: Managerial Behavior, Agency Costs, and Ownership Structure,” Journal of Financial Economics 3, 305-360.

[51] Karim, W., Tony, Z. and Mollah, S. (2013). Impact of Board Ownership, CEO-Chair duality, and foreign equity participation on auditor choice of IPO firms: Evidence from an emerging market. International Journal of Accounting and Information Management, 21(2), 148-169. http://doi.org/10.3386/w19846

[52] Kim, E. H., \& Purnanandam, A. (2013). Seasoned Equity Offerings, Corporate Governance, and Investments. Review of Finance, 18, 1023-1057. doi: 10.1093/rof/rft012.

[53] Kim, H. and A. Purnanandam, 2009, "Corporate Governance and Investor Confidence in Seasoned Equity Offerings," University of Michigan Working Paper.

[54] Klapper, L.F. and I. Love, 2004, "Corporate Governance, Investor Protection and Performance in Emerging Markets," Journal of Corporate Finance10, 703-728.

[55] Koerniadi, H., Krishnamurti, C., Lau, S. T., Tourani-Rad, A., \& Yang, T. (2015). The role of internal and external certification mechanisms in seasoned equity offerings. Journal of Multinational Financial Management, 30, 110-127. doi:10.1016/j.mulfin.2015.04.001.

[56] Kyereboah-Coleman, A. (2008). Performance in Africa: A Dynamic Panel. J. Stud. Econ. Econometrics, 32(2), 1-25.

[57] La Porta, R., Lakonishok, J., Shleifer, A., \& Vishny, R. W. (1997). Good News for Value Stocks: Further Evidence on Market Efficiency. Journal of Finance, 52(2), 859-874. doi:10.2307/2329502.

[58] Laing, D., Weir, C. M., Laing, D., \& Weir, C. M. (2011). Governance structures, size and corporate performance in UK firms. Management Decision, 37(5), 457-464.

[59] Li, X., \& Sun, S. T. (2015). Managerial Ownership and Firm Performance: Evidence From the 2003 Tax Cut. Online Journal, 1-56.

[60] Lincoln, A., Fields, R., \& Adedoyin, O. (2013). Chairman/CEO Duality and its Effects for the Management of Corporate Governance in Guayana. International Journal of Business and Management, 8(20), p36. http://doi.org/10.5539/ijbm.v8n20p36

[61] Linden, P. and Z.P. Matolcsy, 2004, "Corporate Governance Scoring Systems: What Do They Tell Us?" Australian Accounting Review 14(1), 9-16.

[62] Lippert, R.L. and M. Rahman, 1999, "Multinationality, CEO Compensation, and Corporate Governance: Some Empirical Evidence," Managerial Finance 25(10), 1-12.

[63] Liu, W. (2011). Board Independence and Long-term Firm Performance. Unpublished Ph. D Thesis, Universiteit Van Amsterdam, (December).

[64] Liu, Y., Miletkov, M. K., Wei, Z., \& Yang, T. (2015). Board independence and firm performance in China. Journal of Corporate Finance, 30, 223-244. http://doi.org/10.1016/j.jcorpfin.2014.12.004

[65] Loughran, T., \& Ritter, J. (1997). The Operating Performance of Firms Conducting Seasoned Equity Offerings. The Journal of Finance, 52(5), 1823-1850. doi:10.1111/j.15406261.1997.tb02743.x.

[66] Mathiesen, H. (2002). Managerial ownership and financial performance. Unpublished Ph.D. Thesis Submitted to Copenhagen Business School, Department of International Economics and Management.

[67] Mediaty. (2013). The Impact Of Information Asymetry Towards The Quality Of Accrual Earnings With Good Corporate Governance ( GCG ) As Moderating Variabel. IOSR Journal of Economics and Finance, 1(4), 1-5.

[68] Meltem, G., 2009, “The Evolution of Corporate Governance Mechanisms After Going Public: Evidence from Turkish Panel Data," International Journal of Economic Perspectives 3(1), 59-82.

[69] Moscu, R.-G. (2013). Does CEO duality really affect corporate performance? International Journal of Academic Research in Economics and Management Sciences, 2(1), 156166. http://doi.org/10.1111/j.1467-8683.2007.00641.x

[70] Mule, R. K., \& Hons, B. E. (2015). Financial Leverage and Performance of Listed Firms in a Frontier Market: Panel Evidence from Kenya. European Scientific Journal, 11(7), 534-550. 
[71] O’Brien, P.C. and R. Bhushan, 1990, "Analyst Following and Institutional Ownership," Journal of Accounting Research 28, 55-76.

[72] Pathan, S., Skully, M., \& Wickramanayake, J. (2007). Board size, independence and performance: An analysis of thai banks. Asia-Pacific Financial Markets, 14(3), 211-227. http://doi.org/10.1007/s10690-007-9060-y

[73] Paskelian, O. G., \& Bell, S. (2010). The market and operating performance of Chinese seasoned equity offerings. Applied Financial Economics, 20, 649-657. doi:10.1080/09603100903459881.

[74] Peng, M. W., Li, Y., Xie, E., \& Su, Z. (2010). CEO duality, organizational slack, and firm performance in China. Asia Pacific Journal of Management, 27(4), 611-624. http://doi.org/10.1007/s10490-009-9161-4

[75] Price, R., \& Roma, F. J. (2011). The impact of governance reform on performance and transparency. Journal of Financial Economics, 99, 76-96. doi:10.1016/j.jfineco.2010.08.005.

[76] Ramadan, E.-F. (2014). Board of Directors and Tobins Q: Evidence from UK Firms. Journal of Finance and Accounting, 2(4), 82 - 99. doi:DOI:10.12691/jfa-2-4-2.

[77] Rashid, A. (2013). CEO duality and agency cost: Evidence from Bangladesh. Journal of Management and Governance, 17(4), 989-1008. http://doi.org/10.1007/s10997-012-9213-x

[78] Rehman, A., \& Shah, S. Z. A. (2013). Board Independence, Ownership Structure and Firm Performance: Evidence from Pakistan. Interdisciplinary Journal of Contemporary Research In Business, 5(3), 832-845.

[79] Ross, S.A., 1977, "The Determination of Financial Structure: The Incentive- Signaling Approach," Bell Journal of Economics 8, 23-40.

[80] Ruan, W., \& Tian, G Ma, S. (2009). Managerial Ownership and Firm Value: Evidence from China's Civilian-run Firms Managerial. Online Journal, (61), 1-22.

[81] Rüdiger, F., \& Stulz, R. M. (2008). Managerial ownership dynamics and firm value. An Index to the Working Paper in the Fisher College of Business Working Paper Series Is Located at: Http:// www.ssrn.com/link/Fisher-College-ofBusiness.html Fisher.osu.edu, (January).

[82] Sahut, J.-M., \& Gharbi, H. O. (2010). Institutional Investors' Typology and Firm Performance: The Case of French Firms. International Journal of Business, 15(1), 33-50. Retrieved from http://www.craig.csufresno.edu/IJB/Recent Pub.htm\nhttp://search.ebscohost.com/login.aspx?direct=true $\& \mathrm{db}=$ eoh\&AN $=1091250 \&$ site $=$ ehost-live

[83] Sajid, G., Muhammad, S., Nasir, R., \& Farman,a. (2012). Agency cost, corporate governance and ownership structure: the case of Pakistan. International Journal of Business and Social Sciences, 3(9), 268-277. Retrieved from http://mpra.ub.uni-muenchen.de/42418/

[84] Salas, J. M. (2010). Entrenchment, governance, and the stock price reaction to sudden executive deaths. Journal of Banking and Finance, 34(3), 656-666. doi:10.1016/j.jbankfin.2009.09.002.
[85] Sanda, A. U., Garba, T., \& Mikailu, A. S. (2008). Board Independence and Firm Financial Performance: Evidence from Nigeria. Economic Development in Africa, (December 2006), 1-31.

[86] Scholes, M., 1972, "The Market for Securities: Substitution versus Price Pressure and the Effects of Information on Share Prices," Journal of Business 45, 179-211.

[87] Shahid, R., \& Akash, I. (2015). Mediating and Moderating Role of Financial Signaling, Information Asymmetries of Corporate Governance in Debt versus Equity and Market Value Behavior. Pakistan Journal of Commerce and Social Sciences, 9(2), 461-484.

[88] Shuk, J. (1998). Does CEO Duality Matter: An Integrative Approach, 1-158.

[89] Sir Adrian Cadbury. (2003). Let there be light. Internal Auditor, 60(1), 38-46.

[90] Tang, H. (n.d.). CEO Duality and Firm Performance - The Role of External Competition and Internal Governance. Online Journal, 24.

[91] This, I., Lanka, S., Times, T., \& Lankan, T. S. (2009). Does CEO duality really matter? Evidence from an emerging market. Online Journal, 1-23.

[92] Ugwoke, R. O., Onyeanu, E. O., \& Obodoekwe, C. N. (2013). Duality Role of Chief Executive Officer ( CEO ) in Corporate Governance and Performance of Quoted Companies in the Nigerian Stock Exchange: An Appraisal of the Perception of Managers and Accountants.Rearch Journal of Finance Accounting., 4(12), 11-19.

[93] Ujunwa, A. (2012). Board characteristics and the financial performance of Nigerian quoted firms. The International Journal of Business Society, 12(5), 656 - 674. doi:10.1108/14720701211275587.

[94] Wang, K., Chen, Y.-H., \& Huang, S.-W. (2008). Agency Theory and Flotation Methods in Seasoned Equity Offerings: The Case in Taiwan. Review of Pacific Basin Financial Markets and Policies, 11(4), 555-567. doi:10.1142/S0219091508001477.

[95] Wong, J. P. H. F. and T. J. (2005). Do External Auditors Perform a Corporate Governance Role in Emerging Markets ? Evidence from East Asia. Journal of Accounting Research, 43(1), 35-72. doi:10.1111/j.1475-679x.2004.00162.x.

[96] Yang, T., \& Zhao, S. (2012). CEO Duality, Competition, and Firm Performance. SSRN Electronic Journal. http://doi.org/10.2139/ssrn.2177403

[97] Yu, C. J. (2015). Board Independence, Monitoring, and CEO Pay Disparity. Online Journal, 1-24.

[98] Zhu, Y., \& Tian, G. (2009). CEO pay-performance and board independence: the impact of earnings management in China. 4th International Conference on Asia-Pacific Financial Markets (CAFM). Seoul, Korea: Korean Securities Association., 1-39. Retrieved from http://ro.uow.edu.au/commpapers/1890/ 